\title{
THERMAL ANALYSIS OF STRUCTURAL MASONRY IN CONCRETE BLOCK CONTAINING EXPANDED POLYSTYENE (EPS) USING DIGITAL INFRARED THERMAL IMAGE
}

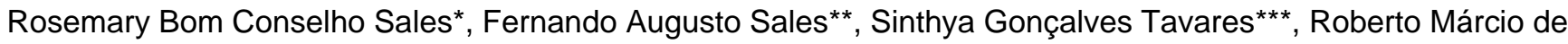

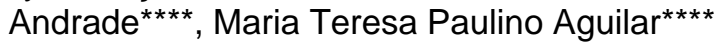 \\ *DETC Dept., State University of Minas Gerais, Av. Antônio Carlos, 7545, Bairro São Luiz, Cep: 31270-010, \\ Belo Horizonte, Minas Gerais, Brasil, rosebcs@gmail.com \\ **DEM Depp., Federal Center for Technological Education in Minas Gerais, Avenida Amazonas, 7675, Cep: \\ 30.510-000, Belo Horizonte, Minas Gerais, Brasil, fdosales@terra.com.br \\ ***DCET Dept., Center University of Belo Horizonte, Av. Professor Mário Werneck, 1685, Estoril, Cep: 30455- \\ 610, Belo Horizonte, Minas Gerais, Brasil, gtavar@terra.com.br \\ ****DEMC Dept.,Federal University of Minas Gerais, Av, Antonio Carlos 6627, Cep:31270-901, Belo Horizonte, \\ Minas Gerais, Brasil, rma@ufmg.br, teresa@demc.ufmg.br.
}

\begin{abstract}
One of the functions of buildings is to provide thermal conditions that are consistent with their environmental comfort. The structural masonry is a widely used constructive system in Brazil. However, it does not provide ideal conditions for thermal comfort within the area, which leads to the use of artificial refrigeration systems by the user. In parallel, from the environmental scope, there is a growing concern with the destination of packages that use expanded polystyrene (EPS), discarded after using. This research examines the thermal performance of a model that uses structural brickwork with EPS as insulation using infrared thermography.
\end{abstract}

Keywords: structural masonry, expanded polystyrene, infrared thermography.

\section{INTRODUCTION}

The constant search for a sustainable development model results in the adoption of attitudes such as energy conserving. The consumption of raw materials and their replacement by recycled raw material is also important. Regarding the construction site, there is a concentration of efforts directed for the use of clean technologies, low power consumption, and lower generation of waste in the built of a comfortable space.

Currently, the buildings are responsible for $42 \%$ of electric power consumption [1], part of that consumption is due to air conditioning systems. Thus, in recent decades, the thermal comfort has been a point of attention of many scholars who, motivated by the energy crisis worldwide, seek ways to save energy to generate heating or cooling as the regional climate demands [2]. The evaluation of thermal performance of a building, according to [3], basically consists of verifying if the materials that will be used in building or several architectural solutions may be taken prior to the construction, therefore avoiding constructions where environments are thermally uncomfortable.

Structural brickwork is a constructive system vastly used in Brazil for construction of small and medium sized buildings. However, considering only the constructive system, it offers no environmental comfort (from a thermal point of view), leading the resident to the use of excessive artificial systems for cooling and therefore to a higher expenditure of electricity [4]. Another problem facing the world today relates to the disposal of waste. The expanded polystyrene has been used increasingly as material for packaging electric appliances, machinery, equipment, etc. This material bears the international symbol EPS (Expanded Polystyrene), better known in Brazil as "Styrofoam ${ }^{\circledR}$ " trademark of Knauf Styrofoam Ltda. According to DIN ISO $1043 / 78$ resolution, this material is identified as a rigid structure cell, resulted from the polymerization of styrene (a by-product of petroleum) in water. The material consists of $98 \%$ air and $2 \%$ of solid matter in the form of polystyrene, which ensures their peculiar physical properties, extremely light weight and excellent thermal and acoustic insulation. The amount of waste from the use of EPS has become a great concern for both government and society, creating the necessity to seek ways to minimize the negative effects of their improper disposal. For this reason, alternative materials, developed from these wastes can be a good choice even in the final cost of materials and methods destinated to construction.

Aiming at the recuperation of EPS waste and seeking to contribute to a sustainable build, this paper studies the thermal performance in a model of masonry containing EPS, using infrared thermography. The thermograph is considered to be a non-destructive non-invasive inspection technique of the temperature range of a surface through thermal infrared radiation generated image, discharded from the surface of any type of material $[5,6,7]$. In the scope of construction, the applications of thermal imaging generally have been used in predictive and preventive maintenance, primarily, and in situations involving the electric current flow or mechanical deterioration, which usually generates heat $[8,9,10]$. 


\section{MATERIALS AND METHODS}

In this work, a thermal camera, Thermovision 570 by Agema, was used to study blocks of concrete masonry with and without EPS as a thermal insulator. The experimental procedure was performed in a laboratory of the Federal University of Minas Gerais - Brazil - Department of Mechanical Engineering and it consisted in the assembly and analysis of four concrete block structure, in which two blocks were filled with EPS beads with approximately 0, $4 \mathrm{~mm}$ in diameter. In the other two blocks the internal cavity remained unfilled. The Picture 1 shows a schematic view of the samples used.

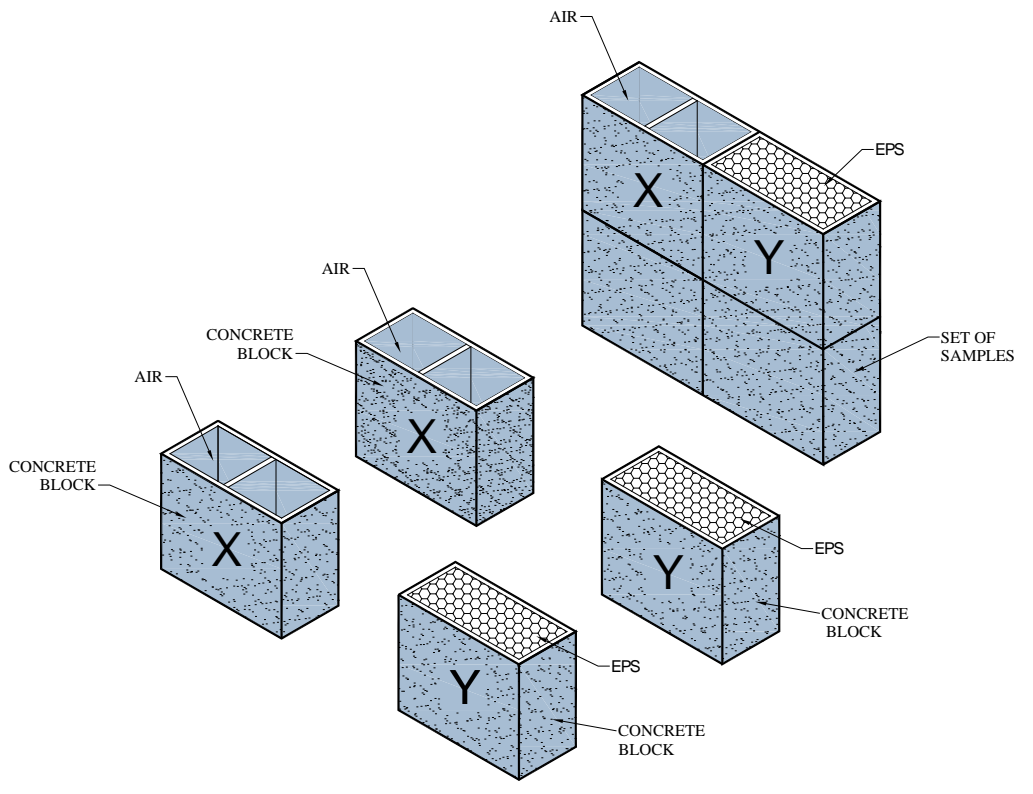

Fig.1 - Concrete blocks filled with EPS $(Y)$ - Non filled EPS concrete block $(X)$.

The concrete samples were prepared and assembled in the outside of the laboratory where they remained 24 hours subject to the climate fluctuation of the local environment (Picture 2). In the morning, infrared thermographies were made. It was decided to artificially heat the blocks using a common heater until the samples reached the ideal temperature for data collection (approximately 1 hour) to get the most revealing images.

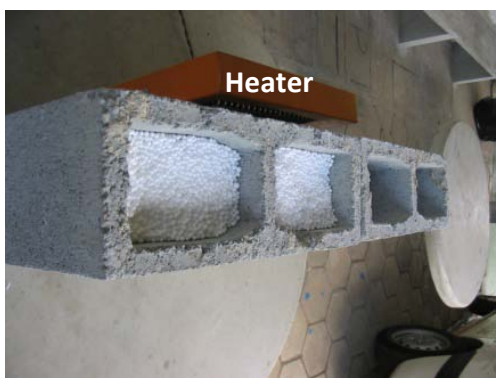

(A)

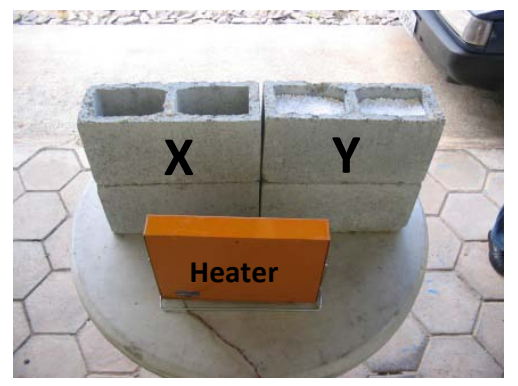

(B)

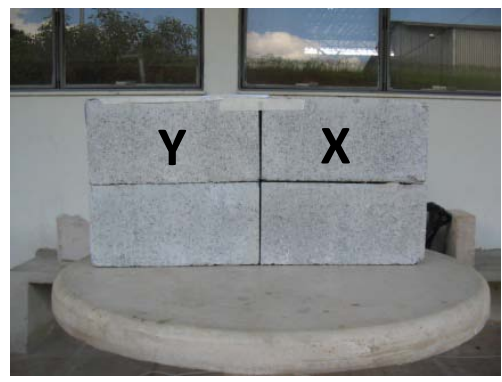

(C)

Fig. 2 - (A) Superior view (B) Posterior view(C) Frontal View

The images were made using a qualitative method, at a $0.50 \mathrm{~cm}(0.19685$ Inches) distance between the measuring equipment and the concrete masonry blocks. The temperature at the time of the sample was $30^{\circ} \mathrm{C}$. The emissivity rate of the system when the reading occurred was 0.75 . 


\section{RESULTS AND DISCUSSION}

The Picture 3 demonstrates the blocks with and without foam padding and their thermal images obtained by infrared thermography. The analysis of the thermographic image shows that there is a difference in the transfer of heat between the two observed samples. The range of colors indicated in the thermogram points out the temperature difference between the samples. The color red concentrated in the area $X$ of the non-filled blocks indicates a higher temperature, and the blue color concentrated in zone $Y$ of the EPS filled blocks indicates a lower temperature. The collected data illustrates that heat crosses zone $\mathrm{X}$ more easily then it does in zone $\mathrm{Y}$.
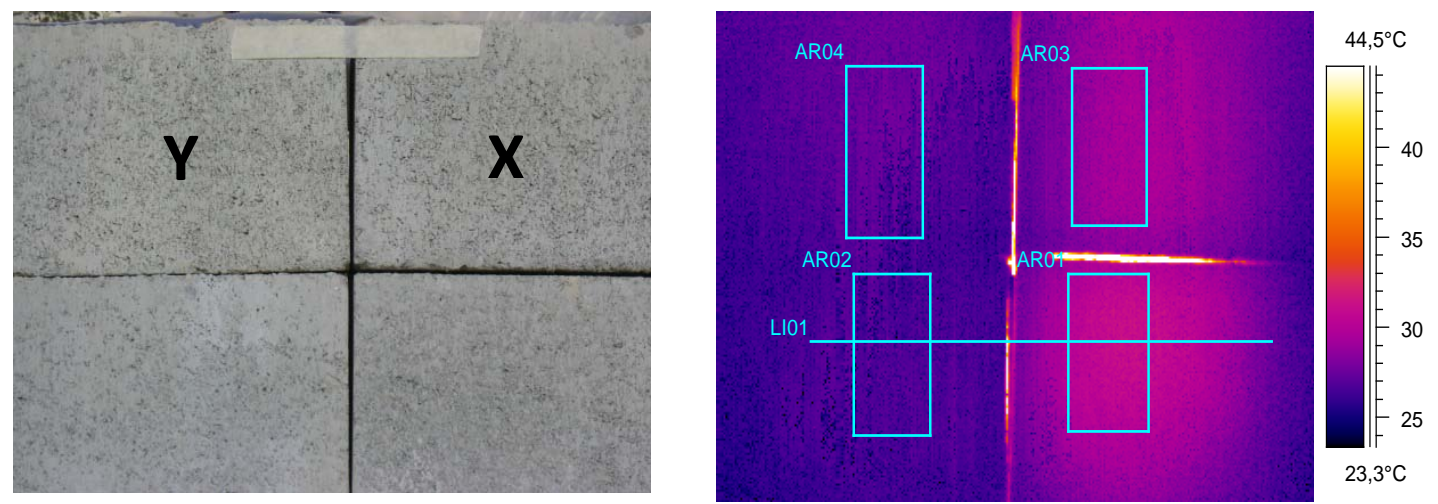

Fig. 3 - Comparison of concrete blocks / Temperature Maps: Infrared camera.

The distribution of the surface temperature of the samples along the Profile Line - L01 in the Picture 3 was recorded by the device and translated into a graphic (Picture 4). The data shows the temperature variation over L01, and its dispersion.

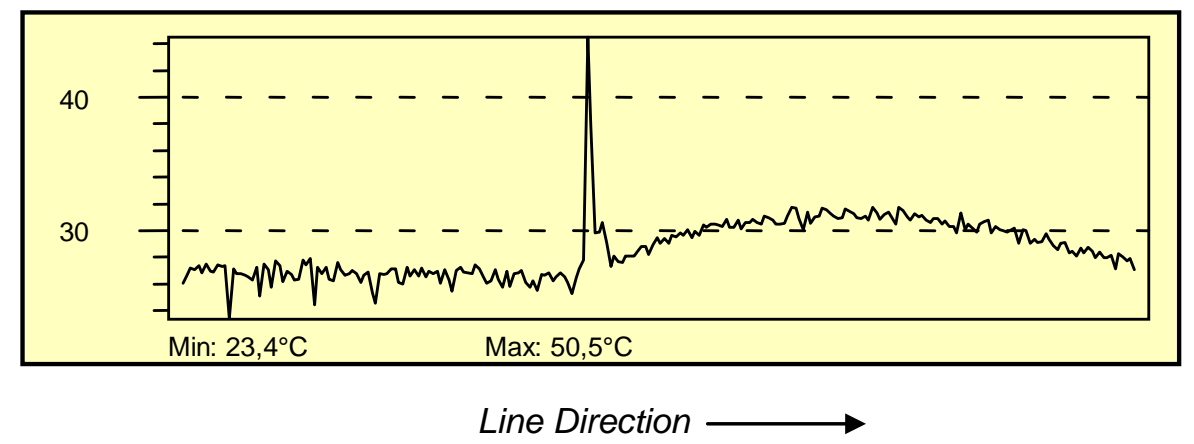

Fig. 4 -Line Profile interpretation

It was possible to observe that the temperatures in zone $\mathrm{Y}$ surrounded $28^{\circ} \mathrm{C}$ and temperatures in zone $\mathrm{X}$ reached $32{ }^{\circ} \mathrm{C}$. The difference between the temperature peaks of each block shows clearly the efficiency disparity amid them.

\section{CONCLUSION}

The results indicate that the thermography technique was efficient in monitoring the quality of the surface temperature of concrete blocks with and without EPS. It was also shown that the residue of EPS is an efficient insulator. Thus, the manufacture of concrete blocks containing EPS, both from a technical and environmental view (lower energy consumption and waste reduction) would be an alternative to improve comfort of the constructed environment. 


\section{ACKNOWLEDGEMENTS}

The authors thank the Research Support Foundation of Minas Gerais State, Brazil (Fundação de Amparo à Pesquisa do Estado de Minas Gerais - FAPEMIG), the National Council for Scientific and Technological Development (Conselho Nacional de Desenvolvimento Científico e Tecnológico - CNPq) for financial support of this research.

\section{REFERENCES}

[1] Lamberts, R.; Dutra, L.; Pereira, F. O. R. Eficiência energética na Arquitetura. São Paulo: 1997, 192p.

[2] Araújo, M. D. Parâmetros de conforto térmico para usuários de edificações escolares no litoral nordestino brasileiro. Natal: Edufrn, 2001.

[3] Krüger, E. L.. A importância do Conhecimento de Térmica em Edificações por Engenheiros Civis. Revista Tecnologia e Humanismo, Curitiba, no 19, p. 18 - 21, ago 1999.

[4] Frota, A.B.; Schiffer, S.R. Manual de conforto térmico. Arquitetura, Urbanismo. $7^{\circ}$ ed. São Paulo: Nobel, 2005.

[5] Castanedo, C.I. Quantitative subsurface defect valuation by pulsed phase thermography: Depth retrieval with the phase. Thèse (obtention grade de Philosophiae Doctor Ph.D.) Faculté des Sciences et de Génie Université Laval - Québec. Octobre 2005.

[6] Maldague, X.P. Theory and practice of infrared technology for nondestructive testing, Wiley \& Sons, Inc., New York, 2001.

[7] Tavares, S.G. Desenvolvimento de uma metodologia para aplicação de ensaios não destrutivos na avaliação da integridade de obras de arte. Tese (doutorado) Escola de Engenharia. Programa de Pós-Graduação: Engenharia Mecânica: Universidade Federal de Minas Gerais. 2006.

[8] Meola, C. et al. Application of infrared thermography and geophysical methods for defect detection in architectural structures. Engineering Failure Analysis, v.12, p.875-892, 2005.

[9] Meola, C.; Carlomagno, G.M. Recent advances in the use of infrared Thermography. Institute of Physics Publishing Measurement Science and Technology, v.15, p.R27-R58, 2004.

[10] Pelizzari, E. Aplicações da Termografia como Ferramenta de Manutenção Preditiva em Conectores Elétricos. $17^{\circ}$. Congresso Brasileiro De Engenharia E Ciência Dos Materiais. Anais..., Foz do Iguaçu, PR, Brasil. 2006. 